\title{
PENGARUH MODEL NUMBER HEAD TOGETHER (NHT) TERHADAP HASIL BELAJAR MATEMATIKA SISWA KELAS IV SD
}

\author{
Beatrix Nian Gupitararas ${ }^{1}$, Wasitohadi ${ }^{2}$ \\ ${ }^{1,2}$ FKIP, Universitas Kristen Satya Wacana, Jl. Diponegoro No. 52 - 60, Salatiga \\ 292016056@student.uksw.edu
}

\begin{abstract}
The purpose of this research is to know effects about number head together and student teams achievement division model to results of learning that there is an increase or not. Number head together used in IV A is experimental and student teams achievement division in IV B is control class. The type of this research is experimental that used pretest and posttest. The pretest used because to know about the first skill of student, then after that used learning give a postest for students that used to know about difference results of pretest and posttest. The test of datas used paired sampel test from SPSS 25,0 for windows application. The class that used number head together is more good that student teams achievement division, from this research is an increase difference used numbere head together and student teams achievement division, the two class were active so they have a sense of competition. The results of this research is for pretest experimental class is $75,33 \%$ and control class is $67,73 \%$ and for posttest experimental class is $84,52 \%$ and control class is $74,42 \%$.
\end{abstract}

Keywords :the learning results, number head together, and students team achievement division

\begin{abstract}
Abstrak
Penelitian ini bertujuan untuk mengetahui pengaruh model pembelajaran number head together dan Student Teams Achievement Division apakah hasil belajar terdapat peningkatan atau tidak. Dimana untuk model pembelajaran number head together dilakukan dikelas IV A yaitu kelas eksperimen dan untuk model pembelajaran Student Teams Achievement Division dilakukan dikelas IV B yaitu kelas kontrol.Penelitian ini termasuk penelitian eksperimen dengan menggunakan pretest dan posttest. Soal pretest dilakukan karena untuk mengetahui kemampuan awal siswa, kemudian setelah itu baru dikenakan penerapan menggunakan model pembelajaran, kemudian yang ketiga baru diberikan soal posttest soal ini digunakan untuk mengetahui apakah meningkat atau tidak hasil belajar siswa. Data yang diperoleh akan diuji dengan menggunakan Paired Sampel TTest dengan bantuan menggunakan aplikasi SPSS 25,0 for windows. Kelas yang dikenai model pembelajaran number head together menghasilkan pemahaman yang leih baik dibandingkan dengan kelas yang di kenai model pembelajaran Student Teams Achievement Division, dari penelitian terdapat juga perbedaan pemahaman dari kelas yang dikenai model number head together dan model pembelajaran Student Teams Achievement Division, kedua kelas tersebut sama sama kelas yang aktif sehingga mempunyai rasa untuk saling bersaing antar kelompok dalam satu kelasnya. Sehingga setelah melakukan penelitian dapat terlihat dari hasil pengerjaan soal pretest untuk kelas eksperimen 75,33\% sedangkan kelas kontrol 67,73\% dan untuk soal posttest kelas ekperimen mendapatkan $84,52 \%$ dan kelas kontrol mendapatkan $74,42 \%$.
\end{abstract}

Kata kunci :Hasil Belajar, Number Head Together, dan Student Teams Achievement

\section{PENDAHULUAN}

Nilai hasil belajar adalah salah satu indicator yang biasa digunakan untuk mengatur suatu keberhasilan dalam belajar siswa. Nilai hasil belajar siswa untuk mencerminkan hasil yang telah tercapai dari segi kognitif,afektif, dan kemampuan pisikomotorik. Dalam mencapai hasil belajar yang tinggi ada beberapa factor yang dapat mempengaruhi siswa dalam belajar diantaranya adalah factor internal yaitu factor yang dari dalam diri siswa itu sendiri dan factor eksternal yaitu factor dari keluarga atau lingkungan luar siswa tersebut. Factor internal dapat terlihat dari kedisiplinan siswa, respon siswa, dan motivasi belajar siswa dari dalam dirinya sendiri, sedangkan untuk factor eksternal dapat terlihat 
dari lingkungan belajar siswa, tujuan pembelajaran, dan pemilihan media atau model pembelajaran yang dilakukan oleh guru. Fakot - factor tersebut sangat mempengaruhi dalam pencapaian hasil belajar yang tinggi dan merupakan satu kesatuan yang mendasari siswa tersebut.

Berdasarkan faktor yang mempengaruhi hasil belajar siswa, model pembelajaran yang dipilih oleh guru menjadi sumber dan berkait dengan factor yang lain. Pemilihan model pembelajaran yang pas dapat membuat suasana belajar menjadi lebih menyenangkan dan memungkinkan untuk siswa dalam mengembangkan kreatifitasnya. Suasana yang menyenangkan akan membuat dampak pada motivasi belajar siswa dan disimpin siswa meningkat. Motivasi belajar yang sangat tinggi menjadi salah satu penentu berhasil atau tidaknya siswa dalam mencapai hasil belajar.

Berdasarkan pendapat guru kelas di SD Negeri Panjang 03 Ambarawa khususnya kelas IV A dan IV B, pada pembelajaran matematika tentang "keliling dan luas bangun datar" pada proses belajar mengajar di kelas dilakukan dengan metode konvensional (ceramah). Ketika proses pembelajaran tersebut berlangsung, banyak siswa yang mengantuk atau ngobrol sendiri, rasa ingin taunya kurang terbangun dan kemandirian dalam kegiatan pembelajaran pun sedikit sekali terlihat ketekunan yang dimiliki belum tampak.

Namun tidak semua siswa seperti itu ada beberapa siswa yang mengajukan pertanyaan terkait dengan materi yang disampaikan oleh guru. Saat mendapatkan nilai yang kurang memuaskan seakan menjadi hasl yang biasa bagi siswa. Siswa tidak termotivasi dalam melakukan kegiatan pembelajaran. Jika hal demikian didiamkan oleh guru maka tujuan pembelajaran tersebut tidak tercapai.

Berdasarkan latar belakang peneliti tertarik untuk melakukan penelitian ekperimen semu dengan menggunakan desain penelitian non - equivalent control group desain yang menggunakan Pretest dan Posttest. Oleh karena itu maka dalam pembelajaran matematika diperulkan adanya pembelajaran yang membuat siswa aktif dalam belajar maka salah satu solusinya yang dilakukan dengan memperbaiki model pembelajaran yang digunakan yaitu Numbere Head Together (NHT) dan Student Teams Achievemnt Division (STAD). Sehingga pada akhirnya nanti dapat dilihat dari model pembelajaran tersebut mana yang lebih baik untuk meningkatkan hasil belajar antara model pembelajaran Numbere Head Together (NHT) dan Student Teams Achievement Division (STAD). Kedua model pembelajaran itu termasuk model pembelajaran kooperatif menurut Trianto (2009: 56) dengan pembelajaran kooperatif dapat mempermudah siswa untuk melangkah memahami konsep.

Menurut Huda (2016 :55) pembelajaran NHT adalah suatu pembelajaran yang memberikan kesempatan siswa untuk saling berbagi pendapat di dalam kelompok kecil dan setiap kelompok mendapatkan nomor yang berbeda - beda, pembelajaran menggunakan model NHT adalah model pembelajaran yang menuntut siswa untuk selalu berfikir bersama kelompok sehingga setiap siswa diberi nomor dan diberi kesempatan untuk menjawab sebuah pertanyaan yang diberikan oleh guru model pembelajaran NHT juga memiliki langkah - langkah yang harus dilakukan saat pembelajaran menurut Trianto, (2009:82) fase 1: penomoran, fase 2: pengajuan pertanyaan, fase 3: berfikir bersama dalam kelompok, fase 4: menjawab pertanyaan dari guru, fase 5: kesimpulan, dan fase 6: reward. 
Selain dengan NHT peneliti juga menggunakan model pembelajaran STAD, model pembelajaran ininjuga termasuk dalam pembelajaran kooperatif yang paling sederhana dan menekankan siswa untuk berinteraksi dengan siswa lain di dalam kelompok. Sehingga menimbulkan siswa yang aktif dalam pembelajaran matematika tersebut yang sangat diperlukan, sehingga pembelajaran lebih bermakna dan pembelajaran matematika tidak lagi dianggap sulit dan menakutkan. Dalam pembelajaran menggunakan model STAD juga harus melewati langkah - langkah menurut Slavin (1990) fase 1: penyajian informasi, fase 2: membagi siswa kedalam kelompok, fase 3: kerja dalam kelompok, fase 4:memberikan soal evaluasi, fase 5: reward. Kokom Komalasari, (2010:63) mengatakan bahwa STAD adalah model pembelajaran mengelompkkan siswa secara heterogen, kemudian siswa yang pandai menjelaskan pada anggota lain sampai semua anggota benar - benar jelas.

Model pembelajaran NHT dan STAD adalah model yang memiliki persamaan dimana kedua model sama - sama belajar dalam kelompok kecil dan siswa saling bekerja sama dengan kelompoknya. Rendahnya hasil belajar siswa dalam pembelajaran matematika materi bangun datar disebabkan juga karena kurang konkrit konsep yang dijelaskan oleh guru sehingga menyebabkan siswa mengalami kesulitan dalam penguasaan konsep. Oleh karena itu untuk meningkatkan hasil belajar siswa guru mampu mengubah pembelajaran dengan menggunakan model pembelajaran yang pas dan strategis, sehingga hasil belajar siswa dapat meningkat.

\section{METODE}

Penelitian ini menerapakan penelitian eksperimen semu dengan desain The Static Group Pretest - Postest Design. Terdapat dua kelas yang digunakan sebagai kelas eksperimen dan kelas kontrol yang akan di kenai penerapan model Number Head Together (NHT) dan Student Teams Achievement Division (STAD). Untuk penerapan model Number Head Together (NHT) akan diterapkan di kelas IV A dan untuk penerapan model Student Teams Achievement Division (STAD) diterapkan di kelas IV B. Mengapa yang dipilih adalah model pembelajaran Student Teams Achievement Division (STAD) untuk mendampingi model pembelajran Number Head Together (NHT) karena model pembelajaran Student Teams Achievement Division (STAD) tersebut adalah model pembelajaran yang sangat sederhana dan model pembelajaran yang hampir sama dengan model pembelajaran Number Head Together (NHT) sama sama menggunakan kelompok kecil dalam menyelesaikan tugas dari guru.Dalam penelitian ini untuk kelas eksperimen menggunakan model Number Head Together (NHT) dan untuk kelas kontrol menggunakan model Student Teams Achievement Division (STAD). Sebelum dikenai penerapan siswa diberikan soal pretest untuk mengetahui kemampuan awal siswa, setelah itu siswa baru diberikan penerapan model pembelajaran dan setelah selesai diberikan penerapan kemudian siswa diberikan soal posttest untuk mengetahui apakah ada peningkatan dihasil belajar siswa.

Penelitian ini bertujuan untuk mengetahui adanya perbedaan pengaruh model pembalajaran Number Head Together (NHT) dan model pembelajaran Student Teams Achievement Division (STAD) terhadap hasil belajar siswa kelas IV SD. Penelitian ini dilakukan di Sekolah SD Negeri Panjang 03 
Ambarawa pada Semester II Tahun ajaran 2019/2020 dengan menggunakan subyek penelitian adalah siswa kelas IV dengan jumlah sampel sebanyak 53 siswa yang terdiri dari kelas IVA atau kelas ekpseimen berjumlah 27 siswa yang diberi model pembelajaran Number Head Together (NHT) dan kelas IVB atau kelas kontrol 26 siswa yang diberi model pembelajaran Student Teams Achievement Division (STAD).

Desain penelitian ini menggunakan desain The Static Group Pretest - Postest Design Penelitian ini melibatkan dua kelas untuk dijadikan kelas penelitian yaitu kelas ekperimen dan kelas kontrol, dimana nanti kedua kelas sebelum dikenai penerapan model akan diberikan soal Pretest dan hari keduanya akan diberikan penerapan model, dan terakhir hari ke 3 akan diberikan soal Posttest, untuk melihat apakah ada perubahan yang meningkat dari sebelum diberikan model dan sesudah diberikan model. Desain penelitian menggunakan The Static Group Pretest - Postest Design berbentuk sebagai berikut:

\section{Tabel 1.}

Desain penelitian The Static Group Pretest - Postest Design

\begin{tabular}{c|c|c|c}
\hline Kelompok & Pretest & Perlakuan & Pascates \\
\hline Eksperimen & $\mathrm{O}_{1}$ & $\mathrm{X}_{1}$ & $\mathrm{O}_{2}$ \\
\hline Kontrol & $\mathrm{O}_{3}$ & $\mathrm{X}_{2}$ & $\mathrm{O}_{4}$ \\
\hline
\end{tabular}

Sumber: Nana Syaodih Sukmadinata

Keterangan:

$\mathrm{O}_{1}$ : nilai pretest kelas eksperimen

$\mathrm{O}_{2}$ : nilai posttest kelas ekperimen

$\mathrm{X}_{1}$ : perlakuan model pembelajaran NHT

$\mathrm{X}_{2}$ : perlakuan model pembelajaran STAD

$\mathrm{O}_{3}$ : nilai pretest kelas kontrol

$\mathrm{O}_{4}$ : nilai posttest kelas kontrol

Teknik pengumpulan data menggunakan teknik tes dan pengamatan. Tes digunakan untuk mengukur kemampuan hasil belajar siswa dan untuk pengamatan dilakukan untuk menilai segi keterampilan. Perolehan hasil akan dibandingkan serta dianalisis menggunakan SPSS 25,0 for windows melalui uji T dengan Independen Sampel T- Test. Teknik analisis data digunakan untuk melihat efektivitas mode pembelajaran Number Head Together (NHT) dan Student Teams Achievement Division (STAD) dengan membandingkan hasil pretest dan posttest hasil belajar. Kemudian setelah dilakukan pretest dan posttest baru dilakukan analisis dan dibandingkan menggunakan SPSS 25,0 for windows melalui uji T dengan Independen Sampel T- Test.

\section{HASIL}

Saat pembelajaran siswa selalu mendapatkan suatu kesempatan yang sama untuk mendorong atau membuat kelompoknya mendapatkan nilai yang maksimal sehingga siswa dapat meenemukan motivasi belajar dengan sendirinya. Dalam kelompok tidak ada pemisah antara siswa yang satu dengan 
siswa yang lain dalam satu kelompok semua bekerja sama dalam kelompok (Shoimin,2014: 51 - 52). Sehingga siswa dapat bekerja sama dengan satu kelompok, dalam kegiatan penelitian sebelum pembelajaran siswa diberikan soal pretest, kemudian baru siswa melakukan kegiatan pembelajaran dengan menggunakan model pembelajaran Number Head Together (NHT) dan Student Teams Achievement Division (STAD). Setalh diberikan penerapan pembelajaran menggunakan model tersebut barulah siswa diberikan soal posttest, kemudian baru dihitung Descriptive Statistics untuk kelas eksperimen

TabeL 2.

Hasil Pretest dan Posttest Hasil Belajar kelas eksperimen

\section{Descriptive Statistics}

\begin{tabular}{ll|l|l|l|l} 
& N & Minimum & Maximum & Mean & Std. Deviation \\
\hline Pretest & 27 & 59 & 100 & 75.33 & 9.888 \\
\hline Postest & 27 & 70 & 100 & 84.52 & 8.487 \\
\hline Valid N (listwise) & 27 & & & & \\
\hline
\end{tabular}

Berdasarkan tabel 2 diperoleh mean dari hasil pretest dan postest sebesar 75,33 dan 84,52 dengan standard devisihasil pretest 9.888 dan posttest 8.487 skor tertinggi pada pretest 100 dan posttest 100, sedangkan skor terrendah pretest 59 dan posttest 70.

\section{Tabel 3.}

Hasil Pretest dan Posttest Hasil Belajar kelas kontrol

\section{Descriptive Statistics}

\begin{tabular}{ll|l|l|l|l} 
& N & Minimum & Maximum & Mean & Std. Deviation \\
\hline Pretest & 26 & 47 & 94 & 67.73 & 13.114 \\
\hline Postest & 26 & 52 & 100 & 74.42 & 11.479 \\
\hline Valid N (listwise) & 26 & & & & \\
\hline
\end{tabular}

Berdasarkan tabel 3 diperoleh mean dari hasil pretest dan postest sebesar 67,73 dan 74,42 dengan standard devisihasil pretest 13.114 dan posttest 11.479 skor tertinggi pada pretest 94 dan posttest 100 , sedangkan skor terrendah pretest 47 dan posttest 52. Keefektifan model Number Head Together (NHT) dan Student Teams Achievement Division (STAD) dapat dilihat melalui uji uji T dengan Independen Sampel T- Test yang sebelumnya harus melalui ji normalitas terleih dahulu dan data dapat dilihat di dalam tabel 3.

\section{Tabel 4.}

Uji Normalitas Kelompok Eksperimen dan Kelompok Kontrol

\section{Tests of Normality}

\begin{tabular}{lc|c|c|c|c|c} 
& \multicolumn{2}{c}{ Kolmogorov-Smirnov ${ }^{\mathrm{a}}$} & \multicolumn{3}{c}{ Shapiro-Wilk } \\
& Statistic & df & Sig. & Statistic & df & Sig. \\
\hline PretestE & .156 & 26 & .105 & .937 & 26 & .115 \\
\hline PostestE & .137 & 26 & $.200^{*}$ & .942 & 26 & .148 \\
\hline PretestK & .131 & 26 & $.200^{*}$ & .950 & 26 & .232 \\
\hline PostestK & .170 & 26 & .051 & .950 & 26 & .234 \\
\hline
\end{tabular}


*. This is a lower bound of the true significance.

a. Lilliefors Significance Correction

Berdasarkan tabel 4 dapat dilihat bahwa dari uji normalitas hasil belajar pretest dan posttest.

Uji normalitas menggunakan SPSS 25.00 for windows jika nilai signifikan >0,05 maka data dikatakan berdistribusi normal dan sebaliknya jika $<0,05$ maka data dikatakan tidak berdistribusi normal.

1. Tingkat nilai signifikan Pretest kelompok eksperimen adalah 0,115 jadi data itu dikatan distribusi normal.

2. Tingkat nilai signifikan Posttest kelompok eskperimen adalah 0,148 jadi data dikatakan distribusi normal.

3. Tingkat nilai signifikan Pretest kelompok kontrol adalah 0,232 jadi data dikatakan distribusi normal.

4. Tingkat nilai signifikan Posttest kelompok kontrol adalah 0,234 jadi data dikatakan distribusi normal.

Berdasarkan uji normalitas dan uji homogenitas yang telah dilakukan, dapat dilihat bahwa skor hasil belajar berdistribusi normal atau homogen, selanjutkan akan dilakukan uji t dengan bantuan SPSS 25.00 for windows. Uji t dilakukan untuk mengetahui ada tidaknya efektifitas antara kelomok eksperimen dan kelompok kontrol terhadap peningkatan hasil belajar siswa pada kelas IV berikut adalah uji t:

\section{Tabel 5.}

Uji T dengan Independen Sampel T- Test

\section{Independent Samples Test}

\begin{tabular}{|c|c|c|c|c|c|c|c|c|c|c|}
\hline & & \multicolumn{2}{|c|}{$\begin{array}{l}\text { Levene's Test } \\
\text { for Equality of } \\
\text { Variances }\end{array}$} & \multicolumn{7}{|c|}{ t-test for Equality of Means } \\
\hline & & \multirow[b]{2}{*}{$\mathrm{F}$} & \multirow[b]{2}{*}{ Sig. } & \multirow[b]{2}{*}{$\mathrm{t}$} & \multirow[b]{2}{*}{$\mathrm{df}$} & \multirow{2}{*}{$\begin{array}{l}\text { Sig. } \\
(2- \\
\text { tailed) }\end{array}$} & \multirow{2}{*}{$\begin{array}{l}\text { Mean } \\
\text { Differ } \\
\text { ence }\end{array}$} & \multirow{2}{*}{$\begin{array}{l}\text { Std. } \\
\text { Error } \\
\text { Differ } \\
\text { ence }\end{array}$} & \multicolumn{2}{|c|}{$\begin{array}{l}95 \% \\
\text { Confidence } \\
\text { Interval of the } \\
\text { Difference }\end{array}$} \\
\hline & & & & & & & & & Lower & Upper \\
\hline \multirow[t]{2}{*}{$\begin{array}{c}\text { Hasil } \\
\text { Belaja } \\
\text { r }\end{array}$} & $\begin{array}{c}\text { Equal } \\
\text { variances } \\
\text { assumed }\end{array}$ & 5.577 & .022 & $\begin{array}{l}5.4 \\
84\end{array}$ & 51 & .000 & $\begin{array}{c}16.56 \\
6\end{array}$ & 3.021 & $\begin{array}{c}10.50 \\
1\end{array}$ & 22.630 \\
\hline & $\begin{array}{c}\text { Equal } \\
\text { variances } \\
\text { not assumed }\end{array}$ & & & $\begin{array}{l}5.4 \\
40\end{array}$ & $\begin{array}{l}42 . \\
525\end{array}$ & .000 & $\begin{array}{c}16.56 \\
6\end{array}$ & 3.045 & $\begin{array}{c}10.42 \\
3\end{array}$ & 22.708 \\
\hline
\end{tabular}

Sehingga dapat dikatan terdapat perbedaan yang signifikan antara model pembelajaran Number Head Together (NHT) dan Student Teams Achievement Division (STAD) karena sig (2 - tailed) menunjukan bahwa kurang dari 0,05 dan $t_{\text {hitung }}$ sebesar 5,484 sedangkan $t_{\text {tabel }} 2,0075$. Jadi jika $t_{\text {hitung }}$ lebih dari tabel maka terdapat perngaruh sehingga dapat dikatakan bahwa $\mathrm{H}_{\mathrm{o}}$ ditolak dan $\mathrm{H}_{\mathrm{a}}$ diterima. Berbagai penelitian mengatakan bahwa model pembeljaran NHT sangatlah efektif untuk pembelajaran matematika pada materi "keliling dan luas bangun datar". Hail ini sesuai dengan yang dikatakan Trianto (2009: 82) proses pembelajaran menggunakan model kooperatif NHT melibatkan banyak anggota 
kelompok untuk memahami materi yang dipelajari dan dapat mengetahui tingkat pemahaman antar siswa terhadap materi tersebut sehingga dapat terlihat apakah hasil belajarnya meningkat atau tidak.

Hasil penelitian sama seperti yang dilakukan dengan oleh Wirani, W dan Bondan, D. (2012) model pembelajaran kooperatif tipe NHT lebih baik dibandingkan dengan tipe STAD dalam meningkatkan kemampuan komunikasi matematis siswa. Hasil penelitian yang dilakukan oleh Ardian,(2014) dalam penelitiannya yang berjudul "Hasil Belajar Siswa yang Diperoleh Melalui Model Pembelajaran Cooperatice Learning tipe NHT dengan STAD pada Materi Pesawat Sederhana di Kelas V SD Negeri 62 Banda Aceh" bahwa hasil belajar siswa yang dapat diperoleh melalui pembelajaran kooperatif tpe Numbered Head Together( NHT) dan model kooperatif tipe Student Team Achievement Division (STAD) tidak terdapat perbedaan yang signifikan. Rofiq Setiawan (2008) telah membuktikan bahawa model pembelajaran NHT lebih baik dibandingkan dengan model pembelajaran ceramah, begitu pula hasil penelitian yang dilakukan oleh Farida Esty Purwasih (2014) mengatakan bahwa penggunakan model pembelajaran NHT memberikan pengaruh yang signifikan dibandingkan dengan model pembelajaran STAD terhadap hasil belajar siswa.

Misbahul Ibad (2013) dalam penelitiannya yang berjudul "Eksperimentasi Pembelajaran Matematika Metode Kooperatif Tipe Student Teams Achievement Divisions (STAD) dan Metode Kooperatif Tipe Numbered Heads Together (NHT) ditinjau dari Gaya Belajar Siswa” juga telah membuktikan bahwa model pembelajaran NHT lebih baik dibandingkan model pembelajaran STAD. Aryana, Agil Al Idrus dan Ahmad Harjono (2015) dalam penelitiannya yang berjudul "Pengaruh Model Pembelajaran Kooperatif NHT dan STAD terhadap Hasil Belajar Sikap Siswa SMA Negeri 2 Gerung" menyatakan bahwa hipotesis awal yang dikemukaan peneliti adalah sikap yang muncul sebagai dampak pengiring proses signifikan antara kelompok model pembelajaran NHT dan model pembelajaran STAD. Penelitian yang lain yang bertolak belakang dengan hasil penelitian saya pernah dilakukan oleh Nita Idriastuti (2016:7) yang mengatakan bahwa tidak terdapat perbedaan yang signifikan pengaruh strategi STAD dan NHT terhadap hasil belajar siswa. Berbanding terbaik dengan yang dilakukan Kusumawati (2014: 251) bahwa perlakuan pembelajaran dengan model NHT memberikan dampak pada hasil belajar yang berbeda dan lebih tinggi dari pada model pembelajaran STAD.

Dalam penelitian yang lain terdapat pula penelitian dari Desi Imanuni (2013) bahwa terdapat perbedaan hasil belajar yang signifikan dalam penerapan model pembelajaran NHT dan STAD, namun nilai dari siswa yang menggunakan model NHT lebih tinggi dari siswa yang menggunakan model STAD. Berbeda dengan penelitian yang dilakukan oleh Kuswoyo, A. (2009) yang menunjukan bahwa model pembelajaran kooperatif tipe STAD lebih efektif dari pada model pembelajaran NHT terhadap kemampuan pemecahan masalah matematika.

\section{KESIMPULAN}

Berdasarkan hasil penelitian yang dilakukan sehingga dapat disimpulkan bahwa model pembelajaran Number Head Together (NHT) lebih efektif dari pada model pembelajaran Student Teams 
Achievement Division (STAD) untuk pengaruh hasil belajar. Hal ini dapat dilihat dari hasil nilai pretest dan posttest mengalami peningkatan dalam hasil belajar matematika. Dalam penelitian ini dapat ditarik kesimpulan bahwa adalanya perbedaan efektivitas yang signifikan dalam penerapan model pembelajaran NHT dan STAD terhadap hasil belajar siswa kelas IV SD. Dari hasil pengerjaan soal pretest kelas eksperimen 75,33 \% sedangkan kelas kontrol 67,73\% dan untuk presentase posttest kelas eskperimen $84,52 \%$ sedangkan kelas kontrol $74,42 \%$.

Hal tersebut dapat ditunjukan dengan menggunakan uji prasyarat yang dilakukan yaitu uji normalitas dan uji homogenitas yang menunjukan bahwa signifikasi dan homogeny, selanjuntya dilakukan uji T Independen Sampel T- Test menunjukan bahwa nilai signifikasinya 0,000 yang berarti bahwa lebih kecil dari 0,05 $(0,000<0,05)$. Dari uji $\mathrm{T}$ menunjukan $t_{\text {hitung }}>t_{\text {tabel }}$ yaitu 5,484 $>2,0075$ dan signifikasinya adalah $0,000<0,05$ yang menunjukan bahwa $\mathrm{H}_{0}$ ditolak dan $\mathrm{H}_{\mathrm{a}}$ diterima. Hal ini dapat menunjukan bahwa terdapat pengaruh yang sangat signifikan dalam penerapan model pembelajara Number Head Together dan Student Teams Achievement Division terhadap peningkatan hasil belajar matematika siswa kelas IV SD.

Saran yang diberikan kepada siswa bahwa siswa mampu belajar menggunakan model pembelajaran tersebut dan lebih menarik menggunakan model pembelajaran NHT karena dapat dilihat dari hasilnya lebih tinggi model NHT. Siswa juga dalam pembelajaran lebih tertarik menggunakan model pembelajaran NHT.

\section{DAFTAR PUSTAKA}

Adrian. (2014). Hasil Belajar Siswa yang Diperoleh Melalui Model Pembelajaran Cooperative Learning tipe NHT dengan STAD pada Materi Pesawat Sederhana di Kelas V SD Negeri 62 Banda Aceh .Unsyiah.

Aryana, I. G., Agil , A. I., \& Ahmad, H. (2015). Pengaruh Model Pembelajaran Kooperatif NHT dan STAD Terhadap Hasil Belajar Sikap Siswa SMA Ngeri 2 Gerung. Jurnal Pijar MIPA, 49 - 56.

E, R. S. (2016). Cooperative Learning Teori, Riset dan Praktik. Bandung : Nusa Media.

H, K. (2014). Perbedaan Penerapan Model Pembelajaran Kooperatif Tipe NHT dan STAD DItinjau dari Hasil Belajar SIswa S. 251.

Huda, M. (2011). Cooperative Learning Metode, Teknik, Struktur dan Model Penerapan. Yogyakarta: Pustaka Pelajar.

Ibad, M. (2013). Eksperimentasi Pembelajaran Matematika Metode Kooperatif Tipe Student Teams Achievement Divisions (STAD) dan Metode Kooperatif Tipe Numbered Heads Together (NHT) ditinjau dari Gaya Belajar Siswa. Universitas Sebelas Maret.

Imanuni, D. (2013). Perbedaan Hasil Belajar Geogratif Siswa Menggunakan Model Pembelajaran Kooperatif Tipe Number Head Together (NHT) dan Student Team Achievement Division (STAD) Kelas XI IPS SMAN 4 Metro Tahun Pelajaran 2012 - 2013. 
Indriastuti, N. (2016). Studi Komparas Strategi Student Teams Achievemen Division (STAD) dan Numbered Head Together (NHT) terhadap Hasil Belajar Matematika SIswa Kelas IV SDN 1 Siswodipuran Boyolali Tahun Ajaran 2015 / 2016 . Universitas Muhammadiyah Surakarta. Isjoni. (2014). Cooperative Learning. Bandung: Alfabeta.

Kuswoyo, A. (2009). Keefektifan Model Pembelajaran Kooperatif Tipe STAD dan NHT Terhadap Kemampuan pemecahan Masalah Matematika pada Materi POkok Kubus dan Balok Kelas VII SMP N 4 Semarang . tidak diterbitkan.

Purwasih, F. E. (2014). Perbedaan Hasil Belajar IPA Biologi Menggunakan Pembelajaran STAD dan NHT siswa kelas VII SMP Negeri 2 Plupuh Sragen Tahun ajaran 2013 / 2014.

Setiawan, R. (2008). Pembelajaran Kooperatif Tipe Number Head Together pada Pokok Bahasa Operasi Hitung Campuran ditinjau dari Motivasi Belajar Siswa.

Slavin E, R. (2016). Cooperative Learning Teori,Riset dan Praktik. Bandung: Nusa Media.

Trianto. (2009). Mendesain Model Pembelajaran Inovatif - Progresif. Surabaya: Kencana.

W, W., \& Bondan , D. (2012). Komparasi Kemampuan Komunikasi Matematis antara Siswa yang diberi Model Pembelajaran Kooperatif tipe NHT dengan STAD kelas VII SMPN 5 Depok . E-Journal Universitas Negeri Yogyakarta, $1: 2$. 